\title{
EQuilibrium
}

Quarterly Journal of Economics and Economic Policy

VOLUME 8 ISSUE 1, 2013

ISSN 1689-765X

\author{
Tetiana Maksimovna Bogolib* \\ Pereyaslav-Khmelnytsky Hryhoriy Skovoroda \\ State Pedagogical University, Ukraine
}

\section{The Public Sector of Mixed Economy in the Modern World}

JEL Classification: $H 4, H 11$

Keywords: mixed economy, public sector, market institutions, liberal capitalism, state property

Abstract: The article examines the processes of rapid development of economic systems of a new type, including mixed economy, shows competitive institutions of the mixed economy, and illustrates the significance of the public sector for the development of the national economy.

\section{Introduction}

At the beginning of the 20th century, the processes of social development have led to the emergence and rapid development of economic systems of a new type, called mixed economy. At present, the concept involves the combination of both competitive and non-competitive mechanisms of creation, distribution and application of public resources. The term "mixed economy" was introduced to describe economic systems which match the idea of free market and planned economy, forming a sort of "mix" of all

(C) Copyright Polish Economic Society Branch in Torun

Date of Submission: December 16, 2011; date of acceptance: February 14, 2013

* Contact: e-mail: ekon.dek@mail.ru, Pereyaslav-Khmelnytsky Hryhoriy Skovoroda State Pedagogical University, Str. Sukhomlinsky 30, r.107, 084001 Ukraine 
these elements. It is doubtful whether an economy can contain an absolute balance between these elements, because any mixed economy is usually characterized by the predominance of either private or public property, or the market, or the public sector (Buchanan 1949, pp. 496-505).

Competitive institutions of mixed economy means that markets use the driving force of competition and pricing mechanisms for the most effective (in terms of market); it means profitable use of resources (lands, labors, funds, information) in the production of public goods. But along with the market institutions there are also other mechanisms of resource allocation, which can be characterized as non-market institutions because they are either non-competitive basis, or have significant limitations. The most important among these institutions is the public sector.

\section{The Origin and Development of a Mixed Economy}

The creation of public sector in the national economy reflects a global process of emergence of a new type of economic system - mixed economy, which is dependent on the correct combination of private and public property. The process of emergence and development of a mixed economy can be analyzed at three levels: scientific - as an idea and its development in a number of concepts, institutional - as the consolidation of these ideas as a system of social, state and market institutions and the final level is empirically - as the actual practice of public institutions of solving social problems and groups. The idea of a mixed economy originated in the late $20^{\text {th }}$ century in the years of the transformation of liberal capitalism into a monopoly and the growth of the state's economic role in these conditions. Just then German economists A. Sheffle and A. Wagner in a number of their scientific works tried to substantiate the idea of "social state" (Sozialstaat), and besides the state intervention in economic processes A. Sheffle called socialism, and A. Wagner called state socialism (Ritter 1989). A. Wagner, as a proponent of "public and Christian socialism" actively developed the conceptual foundations of the social state. This concept included the transformation of the bourgeois state to the "state of culture and welfare", the nationalization of the railways, mining, industrial, bank and insurance companies, and active social integration of citizens in the denial of political and social revolutions (Backhaus 2000). However, the whole theory of the mixed economy has been established as the growth of the role of government, which was only at the beginning of its evolution at that time. 
The more holistic theory of the mixed economy developed by W. Sombart only in the $1920^{\text {ies }}$ of $20^{\text {th }}$ century. In the works "Socialism and the Social Movement" and "Modern capitalism", he equated socialism with all forms of increasing the role of the public sector in the capitalist economy and increasing government intervention in the economy, which gave him the reason to talk about the emergence of a mixed economy (Hansen 2003).

But in practice, after the First World War, the governments of many countries (except the USSR) appealed to the ideals of economic liberalism, market economy received a powerful impetus to the development, numerous economic constraints introduced in the time hostilities were canceled. All those actions increased the economic tensions during the development of the "free market" that led to the global economic crisis of 1929-1933, when they were destroyed by global financial and trading systems, deteriorated the national economy, increased unemployment, and inflation amounted to unprecedented tens, hundreds and thousands of $\%$. The main issue of the economy - the issue of economic development - has become a problem to tackle the crisis. All this led to the creation of new "Keynesian" world economics in which the state became not a minor, but a leading member of the economic interrelation in the system on the macroeconomic level.

After the Second World War, active supporters of the theory of the mixed economy were bourgeois economists E. Hansen, J. Clark, P. Samuelson, J.K. Galbraith, Jan Tinbergen and others (Strachey 1956). They believed that the establishment of a mixed economy is due to the fact that in the advanced capitalist countries, state and private institutions subordinate its activities to the welfare of society, and, in addition, the economic and social activities of the state gradually eliminate the contradictions of capitalism, creating opportunities for economic development and crisis-free economy provides a higher rate of her growth. Somewhat ironically, J.K. Galbraith called the industries that had an active influence of the state "neo-socialist". Slightly different version of the theory of the mixed economy, based on the ideas of the Cambridge school, was developed by the famous ideologists of laborism E. Kroslend and J. Stretch (Samuelson 1964). In their opinion, after the Second World War the transformation of capitalism into another economic system began, its main characteristics being transition of leadership from the owners of funds to the managers of the state economic institutions, ensuring full employment and a steady increase in production as the main task of the modern state. 
The concept of "mixed economy" was introduced in the scientific revolution in the $1960^{\text {ies }}$ of $20^{\text {th }}$ century by P. Samuelson, who defined the American economy as “... a mixed system of free enterprise, economic control, which is carried by both the state and private institutions" (Andrich (ed.), 2008, pp. 577-596). Today, this concept is widely used in various senses, but if we do not take into account individual differences in the modern interpretation of the term by different authors, it can be assumed that a mixed economy is an economic system which in a natural way combines institutional elements of market (private sector) and government (public sector) approaches to the allocation of public resources (Higgs 1985). But in this case the main institutional elements are the interrelation of property, methods of management and control system.

It should also be noted that the concept of a mixed economy is a general undifferentiated in its nature, which suggests the existence of different types of so-called models, depending on the particular value of institutional elements. After taking this into account, the Soviet literature often distinguished liberal (market-oriented, the "American"), social (sociooriented, "German"), social function (state socialism, "Swedish") and state (statist, "Chinese") model of a mixed economy. However, we must recognize this approach as non-productive, since specific institutional features in each case, for each country, create such a wide range of correlations between the main parameters of the economic systems that these models limit cases rather than systematic types.

What is much more interesting is the approach based on the concept of "based on previous development" (Path Dependence Concept), which indicates the existence of two global trends of structural transformation of the world economy, resulting in economic and appear mixed. The first direction - the process of converting the classical market-oriented economies in their transition from industrial to post-industrial stage of development, and the second - the process of structural transformation of the planned centralized economies by introducing institutional elements of the market economy (Higgs 1985). Countries that have implemented these processes have different initial conditions, but their transformation occurred in different directions, but led, in fact, to a single result - the formation of mixed economic systems. It allows to safely consider mixed economy the most common globally and the most modern type of economic activity at the level of the national economy.

The socialist countries in the past had to cover the distance from a centralized economy to a mixed one in an incredibly short time by historical standards, which materially affected both the process of transformation and its current results. Since the beginning of the $1990^{\mathrm{s}}$ 
Ukraine also proceeds this way - it began her active integration into the world economy. Our country as a part of the global economic system has acquired many new features, but also ran into many obstacles in the process of reforming the national economy in the direction of modernizing. Lack own historical experience often forced her to turn to foreign theory and practice of economic reforms, however, we must remember that this is only a guidance concerning their possible solutions on a large historical path of social development in the $21^{\text {st }}$ century.

The formation of the public sector in the economies of developing countries took place half a century before similar process in post-socialist countries and nowadays continues. The beginning of development of the state, this process became known as "development" in economics, in the late $19^{\text {th }}$ century, accelerated significantly in the second half of the $20^{\text {th }}$ century and until today (Van der Weight 1994). This process has cyclical and, at the same time, inertial, irreversible character. It is based on objective factors - the gradual structural changes in the economy, politics and social ideology in their interrelation.

Historical timeline of the process of state expansion reflects its unique cyclical nature (The History of the European Union). The development of the economic functions of the state and the extent of its activities, including as the largest owner, is attributable to the periods of social crises (economic, political - war, revolution, etc.). After overcoming the crisis and changes in the roles and functions of the state, there occurs a period of "liberalization", when stabilization and economic growth lead to a reduction in the economic functions of the state. However, the characteristic feature of this decline in influence of the state is that it does not fall to a level lower than in the previous cycle. This process continues longer with each successive crisis. The general trend of the $20^{\text {th }}-21^{\text {st }}$ centuries was the increase in government spending and expansion of the public sector, by increasing the total activity of the state, it spread on education, health, social insurance and security. This social area grew faster than the economy in general meaning, and therefore rates and government disbursement grow faster (Table 1).

Table 1. Public disbursement in the $19^{\text {th }}-21^{\text {st }}$ century ( $\%$ of GNP)

\begin{tabular}{|l|c|c|c|c|c|c|c|c|c|c|}
\hline \multicolumn{1}{|c|}{ Country } & $\mathbf{1 8 7 0}$ & $\mathbf{1 9 1 3}$ & $\mathbf{1 9 2 0}$ & $\mathbf{1 9 3 7}$ & $\mathbf{1 9 6 0}$ & $\mathbf{1 9 8 0}$ & $\mathbf{1 9 9 0}$ & $\mathbf{2 0 0 0}$ & $\mathbf{2 0 0 5}$ & $\mathbf{2 0 1 0}$ \\
\hline Great Britain & 9,4 & 12,7 & 26,0 & 30,0 & 32,2 & 43,0 & 39,9 & 36,8 & 44,1 & 52,1 \\
\hline Germany & 10,0 & 14,8 & 25,0 & 42,4 & 32,4 & 47,9 & 45,1 & 47,2 & 46,8 & 48,3 \\
\hline Spain & - & 8,3 & 9,3 & 18,4 & 18,8 & 32,2 & 42,0 & 39,1 & 38,4 & 45,6 \\
\hline
\end{tabular}


Table 1 continued

\begin{tabular}{|l|c|c|c|c|c|c|c|c|c|c|}
\hline Country & $\mathbf{1 8 7 0}$ & $\mathbf{1 9 1 3}$ & $\mathbf{1 9 2 0}$ & $\mathbf{1 9 3 7}$ & $\mathbf{1 9 6 0}$ & $\mathbf{1 9 8 0}$ & $\mathbf{1 9 9 0}$ & $\mathbf{2 0 0 0}$ & $\mathbf{2 0 0 5}$ & $\mathbf{2 0 1 0}$ \\
\hline Italy & 11,9 & 11,1 & 22,5 & 24,5 & 30,1 & 41,9 & 53,2 & 46,2 & 48,1 & 50,8 \\
\hline Canada & - & - & 13,3 & 18,6 & 28,6 & 38,8 & 46,0 & 49,9 & 47,8 & 46,9 \\
\hline Netherlands & 9,1 & 9,0 & 13,5 & 19,0 & 33,7 & 55,2 & 54,0 & 46,6 & 43,7 & 49,4 \\
\hline Norway & 3,7 & 8,3 & 13,7 & 17,1 & 29,9 & 37,5 & 53,8 & 45,5 & 42,3 & 44,7 \\
\hline USA & 3,9 & 1,8 & 7,0 & 8,6 & 27,0 & 31,8 & 33,3 & 33,9 & 36,3 & 43,8 \\
\hline France & 12,6 & 17,0 & 27,6 & 29,0 & 34,6 & 46,1 & 49,8 & 51,6 & 53,3 & 55,1 \\
\hline Switzerland & - & 2,7 & 4,6 & 6,1 & 17,2 & 32,8 & 33,5 & 35,1 & 35,3 & 34,2 \\
\hline Sweden & 5,7 & 6,3 & 8,1 & 10,4 & 31,0 & 60,1 & 59,1 & 55,5 & 54,9 & 55,6 \\
\hline Japan & 8,8 & 8,3 & 14,8 & 25,4 & 17,5 & 32,0 & 31,7 & 39,0 & 38,4 & 41,6 \\
\hline EU-27 & - & - & - & - & - & - & - & 44,8 & 46,8 & 50,1 \\
\hline average * & 8,3 & 9,1 & 15,4 & 20,7 & 27,9 & 42,6 & 44,8 & 44,5 & 44,2 & 46,9 \\
\hline
\end{tabular}

Notes: * Arithmetic mean weighted with nominal GNP and public disbursement.

Source: to 1996 - The Economist, 1997, 20 September, 2000-2010 years own calculations from $O E C D$ and EuroStat.

\section{Ideas Socialization of Society and the Results of Nationalization of Major Industries}

As already noted, the historical reasons that led to the increasing role of the state in economic development of classic market types are adapting ideas of "socialization" of society as the evolution of socio-economic and political systems, and the need to counter the economic crisis (such as the Great Depression 1930's) that periodically occur in the private sector, and was its excellent and immeasurable sign. During this period, for the first time, meaning on scientific level, limited and destructive vices regulation of social development through the action of market mechanisms were proved. Governments of developed countries, in response, had to expand the value of the state in economic stabilization (the first wave of nationalization) and solving social problems (social insurance).

Next, more profound and qualitatively different from the previous shift in the functions and activities across the state began in the economies of developed countries during the "militarization" during the Second World War and the reconstruction of war damaged economies of Western Europe and Japan (The Historical Statistics of United States). During this period, 
under the influence of threat occurrence of the general economic crisis, the nationalization of major industries in the private sector was carried out on the largest scale (the second wave of nationalization).

Both crises led to an abrupt change in the scope and functions of the state as an owner and faster growth of the size of the state sector to the private sector. This phenomenon has been most notable in France (state property passed French bank, military industry, railroads, mine industry, "Renault" company, production of electricity, large insurance companies, most of the chemical industry) and in Great Britain (the control of the state shifted Bank of England, mine industry, production of electricity and gas, transport sphere, civil aviation, most steel companies). Some years of this period - 1950-1960 years industrial output of the public sector reached $50 \%$ of GNP (Litorin 1991).

Among the developed countries of that time, United States of America had the smallest size of public sector: the part of the public sector accounted for 12-15\% of GNP (Van der Weight 1994, pp. 193-199). The growth of the state due to the functions of the owner in the USA also done on a much smaller scale in other forms - state played the role of financial assistance (grants, subsidies, loans, government programs, etc.) and counsel for the private sector (foreign trade regulation, public orders, etc.).

The maximum increase in the weight of the public sector in advanced economies has historically been consistent with the qualitative changes in the processes of social development and related to changes in the economy and society. Global changes occurred primarily in the area of social services, which ensure the effective functioning of increasing the value of human capital as a factor of economic growth in the scientific and technological revolution, and the rise in living standards as a factor in the development of "consumption economy" and neutralizer of social conflicts in society. Therefore, the efficiency of the national economy and social stability in developed countries began to directly determine the pace and extent of such sectors as education, health, culture, social protection, social security and others.

The result of a process of nationalization and development of social services was the formation of the structure of new economic sector for developed countries, which functioned on the basis of the public property. Sweden is always mentioned as a limiting case of the model of a mixed economy that emerged at this point in history. The government (represented by the Social Democrats) and the society of this country have implemented national idea of building a "Swedish socialism" based on large-scale public sector (32\% of employment in the country) and huge expenditure on implementation of the economic functions of the state (general government 
expenditures reached to 64\% GNP) (Bureaucracy 1993, pp. 50-54). This was the period of greatest prosperity of theories of the Keynesian type.

\section{The Growing Influence of "Neo-liberal” School of Economic Theory and Activation Processes of Privatization}

The active process of "nationalization" economies in the post-war period quickly led to the overloading state economic and social functions, and the management of state property began to absorb much of the administrative and financial resources of developed countries. State budgets actually become a donor of private sector, on the one hand, they reduced the effectiveness of the impact of market incentives, and on another - at the expense of public funds they were covering the ever-increasing costs associated with the maintenance of social services. Poorly controlled growth of the public sector became the main cause of reduced efficiency of national economies and this has forced governments in developed countries since the 1970's, dramatically changed the priorities of public politic (Bureaucracy 1998, p. 250).

In ideological and conceptual terms, this has led to the growing influence of "neo-liberal" school of economic theory, whose representatives in determining the role and place of state ownership in the modern economy began to actively oppose "neo-Keynesian" theory (Bureaucracy 1998, p. 253). Specifically J.E. Stiglitz, believed that “... lower the effectiveness (of the market) of the public sector is objective in nature, since the difference is due to the system of incentives, both institutional and individual" (Bureaucracy 1998, p. 256). The main difference between public and private enterprise is the threat of bankruptcy faced by private organizations, unlike the state ones, which can always be granted state aid. "The probability of bankruptcy is important, [...] it limits the extent of damage that incompetent manager can reduce private enterprise, and it is a natural mechanism for the replacement of inefficient management personnel" (Bowles (ed.) 1989, pp.107-134). Another fundamental difference between a public and private enterprise is in the absence of competition among the public enterprises. Another important aspect is also less efficient system of individual incentives, due to the fact that the salaries of managers of state enterprises "are rarely so tied to profits as salaries of managers of large private companies".

Based on this and similar reasoning, economic theory and political practice have started to divert private sector role in providing dynamic and ef- 
fective economic development of countries. The basic economic model was recognized as a type of national economy in which the state provides maximum space for private capital and the most liberalized conditions for its operation (Belke (ed.) 2005, p. 39).

The $1970-1980$ 's of the $20^{\text {th }}$ century was marked by the implementation of mass privatization programs of public facilities for developed countries. This process was first started and most consistently completed in the United Kingdom. As a result of privatization in developed countries, the extent of public sector and abbreviated list of the economic functions of the state have significantly reduced. The completion of this process almost coincided with the beginning of structural reforms in the former socialist countries (Table 2).

Table 2. The share of public sector in the economy in some EU countries in 1990 (\%)

\begin{tabular}{|l|c|c|c|c|}
\hline \multicolumn{1}{|c|}{ Country } & Employment & GDP & Investment & Total \\
\hline France & 17,6 & 19,5 & 34,9 & 24,0 \\
\hline Greece & 10 & 19 & 40,6 & 23,2 \\
\hline Portugal & 12,1 & 21 & 35 & 22,7 \\
\hline Italy & 15 & 20 & 26 & 20.3 \\
\hline Spain & 6 & 14 & 21 & 13,6 \\
\hline UK & 9 & 12 & 17 & 12,7 \\
\hline Germany & 10,1 & 11,1 & 16,8 & 12,6 \\
\hline Denmark & 8,2 & 6 & 20 & 11,4 \\
\hline Netherlands & 6,3 & 11 & 7 & 8,1 \\
\hline
\end{tabular}

Source: World Development Report (1997).

\section{Differentiation Share of Public Sector in the Economy of Various Countries}

The marked differentiation in terms of the share of the public sector within the economy was a result of differences in the approaches governments to implement privatization programs. In particular, Germany and the United Kingdom have implemented most consistently liberal approaches, the governments of Italy, France, Greece, Portugal, expressed more caution in the privatization. In choosing the approach of restructuring the state sector of the economy social and political factors played a significant role, for example in the privatization of strategic objects restrictions on the share of private property of capital were introduced. The difference in approach has led 


\section{4}

to significant differentiation in the public sector area, even within the EU member states. The result of mass privatization in 1970-1980's was the formation of the modern configuration of the public sector (Studentsov 1997, p. 41).

The overall trend for developed countries is to maintain a significant share of state property in the areas belonging to the natural monopolies (Table 3).

Table 3. The share of state ownership in natural monopolies in the 1990s (\%)

\begin{tabular}{|l|c|c|c|c|c|c|}
\hline \multicolumn{1}{|c|}{ Country } & $\begin{array}{c}\text { Postal } \\
\text { service }\end{array}$ & $\begin{array}{c}\text { Rail } \\
\text { transport }\end{array}$ & Telecom & $\begin{array}{c}\text { Electric } \\
\text { supply }\end{array}$ & $\begin{array}{c}\text { Gas } \\
\text { Supply }\end{array}$ & $\begin{array}{c}\text { Water } \\
\text { Supply }\end{array}$ \\
\hline USA & 10 & $25-75$ & $<25$ & $25-75$ & $<25$ & $<25$ \\
\hline Japan & 100 & $25-75$ & $<25$ & $<25$ & $<25$ & 100 \\
\hline Germany & 100 & 100 & 80 & $<25$ & $<25$ & $23-75$ \\
\hline France & 100 & 100 & 100 & 100 & 100 & $75-100$ \\
\hline Italy & 100 & 100 & 100 & 100 & 100 & $75-100$ \\
\hline $\begin{array}{l}\text { United } \\
\text { Kingdom }\end{array}$ & 100 & $25-75$ & $<25$ & $25-75$ & $<25$ & $<25$ \\
\hline Canada & 100 & $25-75$ & $25-75$ & 100 & $<25$ & 100 \\
\hline Sweden & 100 & 100 & 100 & $25-75$ & 0 & 100 \\
\hline Spain & 100 & 100 & $<25$ & $25-75$ & $25-75$ & 100 \\
\hline Holland & 100 & 100 & $25-75$ & 100 & $25-75$ & 100 \\
\hline Australia & 100 & 100 & 100 & 100 & $25-75$ & 100 \\
\hline
\end{tabular}

Source: World Development Report (1997, p. 248).

Globalization of the world economy in $1980-1990^{\text {ies }}$ of $20^{\text {th }}$ century accompanied on the one side, the increasing migration of capital and on the another - growing influence on the development of international contention of national economies. This fact prompted the emergence of the system of relations of the establishment of international economic standards and further spread them around the world. These international organizations and regional associations of countries such as the IMF, OECD, WTO, World Bank and the European Union have become active leaders in these standards in the world.

International standards, which were based on liberal principles, to give the public sector rather strictly limited role in the model of the national economy, which consisted mostly to fulfill socially significant functions related to guarantees of security and the economy, ensuring the lives and safety of citizens. The competitiveness of the national economy was considered appropriate to minimize the budgetary revenues from commercial 
activities of the state, because the accumulation of budget revenues through taxes and fees was more effective and less costly.

\section{Conclusions}

The global evolution of the public sector has demonstrated that the interaction of public and private property within the national economy is a cyclical process, with the changing boundaries between them, are external manifestations of deeper and general economic, political and social changes in society.

The end of the beginning of $20^{\text {th }}-21^{\text {st }}$ century started by the series of crises, the impact of which dramatically changes the overall picture of economic and political factors and emphasizes the importance of the modern state and the public sector in the economy. The process of globalization, which was accompanied by further liberalization of the economy, at the same time created the opposite trend in the development of the public sector, in particular, due to activation of mergers and acquisitions. However, the newest most tangible stimulus which increased the economic role of the modern state became the financial crisis and economic recession of the late 2000 's, and the greatest economic contraction in developed countries from 1970's, again demonstrated the limited effectiveness of market mechanisms for self-regulation in modern terms, crisis, private sector and society in general has become state or not only guarantee which can neutralize and overcome its negative effects.

\section{References}

Andrich, H.E., Hodgson Z.M., Hull D.L., Knudsen T., Mokyrj, Vanberg V.J. (2008), In Defense of Generalized Darwinism, "Journal of Evolutionary Economics", Vol. 18, No. 5.

Belke A., Baumgartner F., Schneider F., Setzer R. (2005), The Different Extent of Privatization Proceeds in EU Countries: A Preliminary Explanation Using a Public Choice Approach, IZA Discussion Paper No 1741, September.

Bowles S., Gordon D. (1989), Business ascendancy and economic impasse: A Structural Retrospective on Conservative Economics, 1979-87, "Journal of Economic Perspectives", Vol. 3, No. 1.

Buchanan J.M. (1949), The pure theory of government finance: a suggested approach, "Journal of Political Economy", No. 57.

Hansen A. (2003), Fiscal Policy and Business Cycles, "Business \& Economics", No. 8. 
Higgs R. (1985), Crisis, the growth of the state and ideological strike-slip faults, two hypotheses about the "inertial phenomena", http://liberty-belarus. info.

Jurgen G. Backhaus, Hg. Werner Sombart (2000), Klassiker der Sozialwissenschaft. Eine kritische Bestandsaufnahme, Marburg.

Litorin S.O. (1991), The collapse of the socialist myth. The rise and fall of the welfare state in Sweden, Fund Referendum-Polifakt, Minsk.

Mises L. (1993), Bureaucracy. Planned Chaos. Anti-capitalist mentality.

Ritter G. (1989), Der Sozialtaat - Entstehung und Entwicklung im international len Vergfeich, Munchen.

Samuelson P. (1964), Economy: Basic course.

Strachey J. (1956), Contemporary Capitalism.

Studentsov V.B. (1997), Public business enterprise: Theory and Economy, " Society and Economy", No3-4.

Stiglits J.E. (1998), Economy of state sector, Basis.

The Historical Statistics of United States, http:/hsus.cambrdge.org/HSU SWeb/HSU S Entry Servlet.

The History of the European Union, http://europa.eu/abc/history/index_en.htm.

Van der Weight G. (1994), History of the world economy 1945-1990, Nauka, Moscow.

Webknow, Word Press. http://www.webknow.org/.

World Bank (1997), World Development Report 1997- The State in a Changing World, http://www-wds.worldbank.org/external/default/WDS Content Server/ IW3P/IB/1997/06/01/00000 9265_3980217141148/Rendel ed/PDF/multi O page.pdf. 